\title{
Activation of C-H Bonds $\alpha$ to Nitriles for Combinatorial Chemistry: Ruthenium-Catalyzed Aldol and Michael Reactions of Polymer-Supported Nitriles
}

\author{
Hikaru Takaya, Shun-Ichi Murahashi* \\ Department of Chemistry, Graduate School of Engineering Science, Osaka University, 1-3 Machikaneyama, Toyonaka, Osaka, 560-8531, \\ Japan \\ Fax +81-6-6850-6224; E-mail: mura@ chem.es.osaka-u.ac.jp \\ Received 31 January 2001
}

\begin{abstract}
Catalytic activation of $\mathrm{C}-\mathrm{H}$ bonds adjacent to nitriles supported by Wang resin can be performed with ruthenium dihydride complex $\mathrm{RuH}_{2}\left(\mathrm{PPh}_{3}\right)_{4}(\mathbf{1})$. Aldol and Michael reactions of the solid-supported cyanoacetates proceed to give the corresponding adducts in good yields under mild and neutral conditions. Fourcomponent reactions that include sequential aldol-Michael-Michael reaction by $\mathrm{C}-\mathrm{H}$ activation take place diastereoselectively.
\end{abstract}

Key words: ruthenium, C-H activations, solid-phase synthesis, nitriles, aldol reactions, Michael additions

Solid-phase organic synthesis is currently of considerable interest in the context of combinatorial synthesis towards construction of high-throughput processes, and it is a widely used as a key technology for pharmaceutical research. ${ }^{1}$ Particularly, solid-phase organic synthesis with transition-metal complex catalysts is one of the most important chemistry for combinatorial synthesis; development of new solid-phase reactions and transferring solution-phase reactions to solid-phase have rapidly become an area of intense research activity. ${ }^{2}$ Many reports on transition-metal-catalyzed reactions for solid-phase synthesis have been appeared $;^{3}$ however, very little is known about carbon-carbon bond forming reaction induced by $\mathrm{C}-\mathrm{H}$ bond activation with transition-metal complexes. ${ }^{1,2}$ Carbon-carbon bond formations induced by C$\mathrm{H}$ activations will provide a new method for solid-phase organic synthesis, because these reactions proceed highly selectively under mild and neutral reaction conditions without formation of inorganic salts. Therefore, the amount of time, efforts, and cost for neutralization, protection/deprotection processes, and wash off salts can be reduced.

As a line of our study on the development of C-H activation induced by $\alpha$-heteroatom effect, ${ }^{4}$ we have found that low-valent transition-metal complexes are effective catalysts for the $\alpha-\mathrm{C}-\mathrm{H}$ activations of amines, ${ }^{5}$ nitriles, ${ }^{6,7}$ and isonitriles. ${ }^{8}$ This concept led us to find the low-valent ruthenium-catalyzed $\alpha-\mathrm{C}-\mathrm{H}$ activation of nitriles on solidphase (equation 1). Ruthenium-coordinated nitriles tethered to Wang resin undergo $\alpha-\mathrm{C}-\mathrm{H}$ activation to give cyanoalkyl intermediate. Capture of the intermediate with electrophiles such as carbonyl compounds and electrondeficient olefins provides aldol and Michael reactions of polymer-supported nitriles under mild and neutral reac-

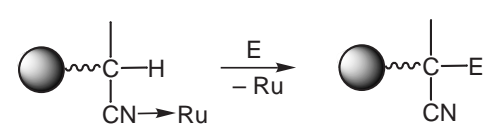

Equation 1

tion conditions. Herein, we wish to report the first example of ruthenium-catalyzed $\mathrm{C}-\mathrm{H}$ activation on solid-phase and carbon-carbon bond formation of supported nitriles.

Ruthenium dihydride complex $\mathrm{RuH}_{2}\left(\mathrm{PPh}_{3}\right)_{4}(\mathbf{1})$ has proven to be a good catalyst for $\alpha-\mathrm{C}-\mathrm{H}$ activation of polymersupported nitriles. Aldol and Michael reactions of the cyanoacetate $\mathbf{2}$ supported on Wang resin ${ }^{9}$ can be performed catalytically at room temperature under neutral conditions (Scheme 1). The resin 2 was obtained by

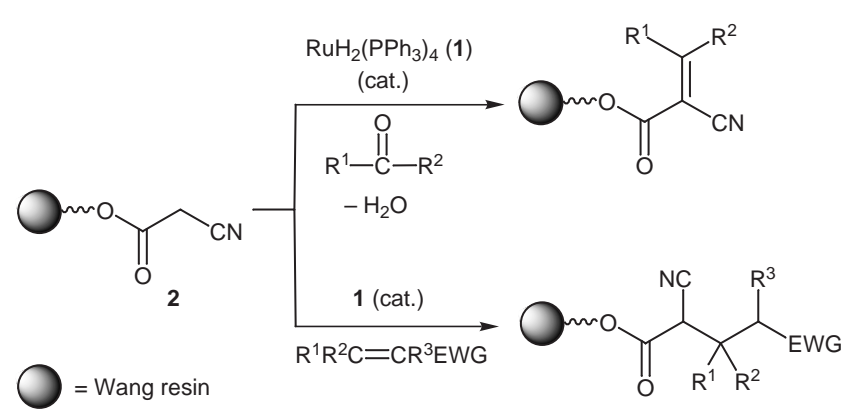

Scheme 1

esterification of the commercially available Wang resin with cyanoacetic acid. ${ }^{10}$ The representative results of the $\mathrm{RuH}_{2}\left(\mathrm{PPh}_{3}\right)_{4}$-catalyzed reaction of supported nitriles with carbonyl compounds are shown in Table. ${ }^{11}$ Upon treatment of the resin 2 with benzaldehyde in the presence of $5 \mathrm{~mol} \%$ of $\mathbf{1}$, aldol condensation proceeds to give the corresponding polymer-bound $\alpha, \beta$-unsaturated nitrile 3 nearly quantitatively (entry 1). ${ }^{12}$ The yield of $\mathbf{3}$ was determined by ${ }^{1} \mathrm{H}$ HRMAS NMR based on the original loading of cyanoacetic acid on the resin 2 . Transesterification of $\mathbf{3}$ with $\mathrm{MeOH}-\mathrm{DMF}_{-} \mathrm{Et}_{3} \mathrm{~N}$ gave methyl $(E)$-2-cyano-3-phenylpropenoate in $95 \%$ isolated yield. Cleavage of 3 with TFA in $\mathrm{CH}_{2} \mathrm{Cl}_{2}$ afforded 2-cyano-3-phenylpro- 
penoic acid in $79 \%$ yield. Condensation of $\mathbf{2}$ with aliphatic carbonyl compounds such as butyraldehyde, 3-cyclohexane-1-carboxaldehyde, and cyclohexanone gives the corresponding products efficiently (entries 2-4). Importantly, the yields obtained are similar to those obtained from the solution-phase reaction with $\mathbf{1}$ as previously reported, ,a,b indicating that penetration of catalyst $\mathbf{1}$ into the resin is allowed well. Michael reaction of $\mathbf{2}$ with electron-deficient olefins such as acrylonitrile occurred to give the corresponding adducts (entry 5). Chemo- and stereoselectivity were obtained, when crotonaldehyde and benzalacetone are used $^{7 \mathrm{a}, \mathrm{b}}$ (entries 6 and 7).

Table Ruthenium-Catalyzed Aldol and Michael Reactions of Polymer-Supported Cyanoacetic Acids ${ }^{\mathrm{a}}$

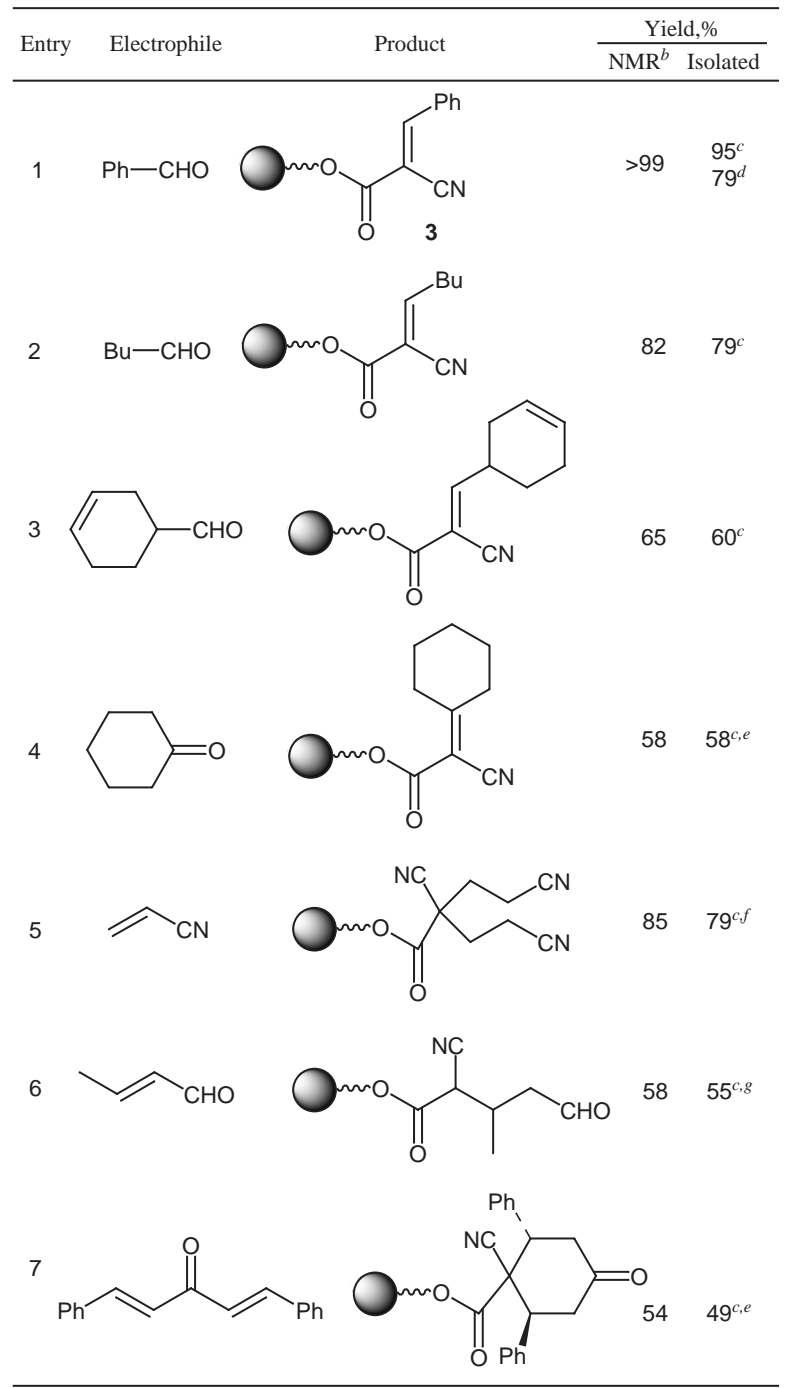

${ }^{a}$ The reaction was carried out according to the typical procedure. ${ }^{13}$ ${ }^{\mathrm{b}}$ Conversion was determined by ${ }^{1} \mathrm{H}$ HRMAS NMR analysis. ${ }^{\mathrm{C}}$ Isolated yield after cleavage by transesterification $\left(\mathrm{MeOH}-\mathrm{DMF}-\mathrm{Et}_{3} \mathrm{~N}\right)$ based on the original loading of cyanoacetic acid on Wang resin. ${ }^{\mathrm{d}}$ Isolated yield after acidic cleavage (TFA- $\mathrm{CH}_{2} \mathrm{Cl}_{2}$ ). ${ }^{\mathrm{e}}$ Reaction conditions; THF $(5.0 \mathrm{~mL}), 6{ }^{\circ} \mathrm{C}, 30 \mathrm{~h} .{ }^{\mathrm{f}} 4.0 \mathrm{mmol}$ of acrylonitrile was used. ${ }^{\mathrm{g}}$ Diastereomer ratio $=44 / 56$.
Development of multicomponent reactions in which three or more reactants combine in one step synthesis has been an emerging area in pharmaceutical research that will dramatically reduce the time and cost for the preparation of chemical libraries. ${ }^{1,2}$ The efficiency of the present reaction is demonstrated by diastereoselective tandem Michael addition reaction arising from chelation control of ruthenium. In the presence of catalyst $1(10 \mathrm{~mol} \%)$, the reaction of $\mathbf{2}$ with dimethyl methylidenemalonate and subsequent addition of methyl vinyl ketone in $\mathrm{CH}_{2} \mathrm{Cl}_{2}$ at $60{ }^{\circ} \mathrm{C}$ occurred with high diastereoselectivity (equation 2). ${ }^{13}$ After cleavage with $\mathrm{MeOH}-\mathrm{DMF}_{-} \mathrm{Et}_{3} \mathrm{~N}$, a mixture of methyl $\left(3 R^{*}, 4 S^{*}\right)$-2,4-bis(methoxycarbonyl)-4-cyano-3-

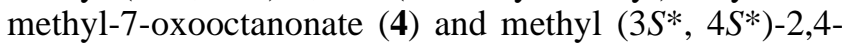
bis(methoxycarbonyl)-4-cyano-3-methyl-7-oxoocta-nonate (5) was obtained in $65 \%$ isolated yield. ${ }^{14}$ It is noteworthy that extremely high diastereoselectivity $(\mathbf{4} / \mathbf{5}=96 / 4)$ was obtained because of chelation effect of ruthenium.<smiles>C=CCOC(=O)C(C)(CCC(C)=O)C(=O)OOC(=O)C(C)(CCC(C)=O)C(C)C(CCC(C)=O)C(C)=O</smiles>

Equation 2

The efficiency of the present reaction is highlighted by diastereoselective four component reactions as shown in Scheme 2. The ruthenium-catalyzed reaction of $\mathbf{2}$ with aldehydes and subsequent<smiles>C=CCC(=O)OCC(C)=O</smiles>

Scheme 2 
Michael addition of carbon pronucleophiles to electrondeficient olefins can be performed to give the corresponding adducts diastereoselectively. Actually, the sequential reaction of $\mathbf{2}$ with acetoaldehyde, dimethyl malonate, methyl vinyl ketone gave 4 in $40 \%$ yield. The diastereoselectivity is again very high $(\mathbf{4 / 5}=90 / 10)$. Formation of the intermediates 6 and 7 were confirmed by ${ }^{1} \mathrm{H}$ HRMAS NMR experiments.

In summary, we found the first catalytic aldol and Michael reactions of nitriles tethered to solid support initiated by $\alpha-\mathrm{C}-\mathrm{H}$ activation of nitriles by using low-valent ruthenium complexes. These reactions will provide a wide scope of carbon-carbon bond formation for solid-phase organic synthesis.

\section{Acknowledgement}

This work was supported by Research for the Future program, the Japan Society for the Promotion of Science and a Grant-in-Aid for Scientific Research, the Ministry of Education, Culture, Sports, Science, and Technology of Japan.

\section{References and Notes}

(1) For solid-phase organic chemistry, see (a) Obrecht, D.; Villalgordo, J. M. Solid-Supported Combinatorial and Parallel Synthesis of Small-Molecular-Weight Compound Libraries; Elsevier Science: Oxford, 1998. (b) Dörwald, F. Z. Organic Synthesis on Solid Phase: Supports, Linkers, Reactions; Wiley-VCH: Weinheim, 2000. (c) Burgess, K. Solid-Phase Organic Synthesis; Wiley: New York, 2000.

(2) (a) Thompson, L. A.; Ellman, J. A. Chem. Rev. 1996, 96, 555. (b) Hermkens, P. H. H.; Ottenheijm, H. C. J.; Rees, D. Tetrahedron 1996, 52, 4527. (c) Früchtel, J. S.; Jung, G. Angew. Chem., Int. Ed. Engl. 1996, 35, 17. (d) Balkenhohl, F.; Bussche-Hünnefeld, C.; Lansky, A.; Zechel. C. Angew. Chem., Int. Ed. Engl. 1996, 35, 2288. (e) Hermkens, P. H. H.; Ottenheijm, H. C. J.; Rees, D. C. Tetrahedron 1997, 53, 5643. (f) Lam, K. S.; Lebl, M.; Krchnák, V. Chem. Rev. 1997, 97, 411. (g) Brown, R. C. D. J. Chem. Soc., Perkin Trans. 1 1998, 3293. (h) Brown, A. R.; Hermkens, P. H. H.; Ottenheijm, H. C. J.; Rees, D. C. Synlett 1998, 817. (i) Kingsbury, C. L.; Mehrman, S. J.; Takacs, J. M. Curr. Org. Chem. 1999, 3, 497. (j) James, I. W. In Annual Reports in Combinatorial Chemistry and Molecular Diversity, Vol 2; Pavia, M. R.; Moos, W. H., Eds.; Kluwer Academic: Leiden, 1999; p 129.

(3) For transition-metal-catalyzed reactions on solid-phase, see Cr: (a) Annis, D. A.; Helluin, O.; Jacobsen, E. N. Angew. Chem., Int. Ed. Engl. 1998, 37, 1907. Ru: (b) Miller, S. J.; Blackwell, H. E.; Grubbs, R. H. J. Am. Chem. Soc. 1996, 118, 9606. (c) Nicolau, K. C.; Winssinger, N.; Pastor, J.; Ninkovic, S.; Sarabia, F.; He, Y.; Vourloumis, D.; Yang, Z.; Li, T.; Giannakakou, P.; Hamel, E. Nature 1997, 387, 268. Os: (d) Riedl, R.; Tappe, R.; Berkessel, A. J. Am. Chem. Soc. 1998, 120, 8994. Co: (e) Schore, N. E.; Najdi, S. D. J. Am. Chem. Soc. 1990, 112, 441. Rh: (f) Ojima, I.; Tsai, C.-Y.; Zhang, Z. Tetrahedron Lett. 1994, 35, 5785. Pd: (g) Young, J. K.; Nelson, J. C.; Moore, J. S. J. Am. Chem. Soc. 1994, 116, 10841. (h) Plunkett, M. J.; Ellman, J. A. J. Am. Chem. Soc. 1995, 117, 3306. Pt: (i) Brown, D.; Armstrong, R. W. J. Am. Chem. Soc. 1996, 118, 6331.

(4) For $\alpha$-heteroatom effect, see Murahashi, S.-I.; Naota, T. Bull. Chem. Soc., Jpn. 1996, 69, 1805.
(5) (a) Murahashi, S.-I.; Hirano, T.; Yano, T. J. Am. Chem. Soc. 1978, 100, 348. (b) Murahashi, S.-I.; Watanabe, T. J. Am. Chem. Soc. 1979, 101, 7429.

(6) For reviews on C-H activation of nitriles, see (a) Naota, T.; Murahashi, S.-I.; Takaya, H. Chem. Rev. 1998, 98, 2599. (b) Murahashi, S.-I.; Takaya, H. Acc. Chem. Res. 2000, 33, 225.

(7) (a) Naota, T.; Taki, H.; Mizuno, M.; Murahashi, S.-I. J. Am. Chem. Soc. 1989, 111, 5954. (b) Murahashi, S.-I.; Naota, T.; Taki, H.; Mizuno, M.; Takaya, H.; Komiya, S.; Mizuho, Y.; Oyasato, N.; Hiraoka, M.; Hirano, M.; Fukuoka, A. J. Am. Chem. Soc. 1995, 117, 12436. (c) Takaya, H.; Naota, T.; Murahashi, S.-I. J. Am. Chem. Soc. 1998, 120, 4244.

(8) Takaya, H.; Kojima, S.; Murahashi, S.-I. Org. Lett. 2001, 3, 421.

(9) Polystyrene based $p$-benzyloxybenzyl alcohol resin, see Wang, S.-S. J. Am. Chem. Soc. 1973. 95. 1328. The Wang resin 100-200 mesh with a loading of $0.83 \mathrm{mmol} / \mathrm{g}$ was purchased from Nova Biochem.

(10) The procedure for preparation of 2: A mixture of cyanoacetic acid (634.4 mg, $7.38 \mathrm{mmol})$, diisopropylcarbodiimide $(931.4$ $\mathrm{mg}, 7.38 \mathrm{mmol})$, Wang resin $(3.0 \mathrm{~g})$, 4-dimethylaminopyridine (61.1 $\mathrm{mg}, 0.5 \mathrm{mmol})$, and anhydrous DMF $(100 \mathrm{~mL})$ was stirred and refluxed for $12 \mathrm{~h}$. The resin was filtered off and washed thoroughly (DMF, $\mathrm{MeOH}$, and $\mathrm{CH}_{2} \mathrm{Cl}_{2}$ ), and the product resin was used directly for the present reactions. FTIR and high-resolution ${ }^{1} \mathrm{H}$ magic angle spinning NMR $\left({ }^{1} \mathrm{H}\right.$ HRMAS NMR) analyses confirmed that the hydroxyl group of Wang resin was converted to the cyanoacetate in $>99 \%$. Selected data for resin 2: IR (KBr) 2275 (w, CN), 1742 (s, $\mathrm{C}=\mathrm{O}) \mathrm{cm}^{-1} ;{ }^{1} \mathrm{H} \mathrm{HRMS} \mathrm{NMR}\left(\mathrm{CDCl}_{3}, 500 \mathrm{MHz}\right) \delta 3.29(\mathrm{~s}, 2 \mathrm{H}$, $\left.-\mathrm{O}_{2} \mathrm{CCH}_{2} \mathrm{CN}\right)$.

(11) All reactions were monitored by FTIR and high-resolution ${ }^{1} \mathrm{H}$ HRMAS NMR. The ${ }^{1} \mathrm{H}$ HRMAS NMR analyses were carried out on a Varian Unity-INOVA $500 \mathrm{MHz}$ NMR spectrometer equipped with a Nano NMR probe, and the Wang resin was swelled in $\mathrm{CDCl}_{3}$ or $\mathrm{CD}_{2} \mathrm{Cl}_{2}$.

(12) A typical procedure for aldol and Michael reactions of $\mathbf{2}$ is as follows: A mixture of resin $2(500 \mathrm{mg}, 0.83 \mathrm{mmol} / \mathrm{g}, 0.415$ $\mathrm{mmol}$ ), catalyst $\mathbf{1}(23.9 \mathrm{mg}, 0.0208 \mathrm{mmol})$, and degassed $\mathrm{CH}_{2} \mathrm{Cl}_{2}(5.0 \mathrm{~mL})$ was stirred at room temperature under argon atmosphere. After stirring for $2 \mathrm{~h}$, carbonyl compounds or electron-deficient olefins $(1.0 \mathrm{mmol})$ was added to the mixture and stirred for $30 \mathrm{~h}$. The resin was then filtered and washed successively with 3 times each with toluene and $\mathrm{MeOH}$. After drying to a constant weight, the resin was analyzed by ${ }^{1} \mathrm{H}$ HRMAS NMR to determine the conversion yield. Selected data for compounds 3: IR (KBr) $2195(\mathrm{~m}, \mathrm{CN}), 1745$ $(\mathrm{s}, \mathrm{C}=\mathrm{O}) \mathrm{cm}^{-1} ;{ }^{1} \mathrm{H}$ HRMS NMR $\left(\mathrm{CDCl}_{3}, 500 \mathrm{MHz}\right) \delta 7.40-$ $7.58\left(\mathrm{~m}, 3 \mathrm{H}, \mathrm{C}_{6} H_{5}\right), 7.90\left(\mathrm{br}, 2 \mathrm{H}, \mathrm{C}_{6} H_{5}\right), 8.22(\mathrm{~s}, 1 \mathrm{H}$, $\left.=\mathrm{C} H\left(\mathrm{C}_{6} \mathrm{H}_{5}\right)\right)$.

(13) Reactions were carried out in a Teflon-cocked sealed glass tube purchased from Ace Glass Inc.

(14) Selected spectroscopic data for compound 4: mp. 107.2 ${ }^{\circ} \mathrm{C}$; IR (KBr) $2317(\mathrm{CN}), 1740(\mathrm{C}=\mathrm{O}) ;{ }^{1} \mathrm{H} \mathrm{NMR}\left(\mathrm{CDCl}_{3}, 500 \mathrm{MHz}\right)$ $\delta 1.29\left(\mathrm{~d}, J=7.0 \mathrm{~Hz}, 3 \mathrm{H}, \mathrm{CHCH}_{3}\right), 2.17(\mathrm{~s}, 3 \mathrm{H}$, $\mathrm{CH}_{2} \mathrm{CH}_{2} \mathrm{COCH}_{3}$ ), 2.18 (ddd, $J=4.5,10.5,18.0 \mathrm{~Hz}, 1 \mathrm{H}$, $\mathrm{CH}_{2} \mathrm{CH}_{2} \mathrm{COCH}_{3}$ ), 2.25 (ddd, $J=4.5,10.5,18.0 \mathrm{~Hz}, 1 \mathrm{H}$, $\mathrm{CH}_{2} \mathrm{CH}_{2} \mathrm{COCH}_{3}$ ), 2.47 (ddd, $J=4.5,10.5,18.0 \mathrm{~Hz}, 1 \mathrm{H}$, $\mathrm{CH}_{2} \mathrm{CH}_{2} \mathrm{COCH}_{3}$ ), 2.71 (ddd, $J=4.5,10.5,18.0 \mathrm{~Hz}, 1 \mathrm{H}$, $\left.\mathrm{CH}_{2} \mathrm{CH}_{2} \mathrm{COCH}_{3}\right), 2.94\left(\mathrm{dq}, J=5.0,7.0 \mathrm{~Hz}, 1 \mathrm{H}, \mathrm{CHCH}_{3}\right)$, $3.55\left(\mathrm{~d}, J=5.0 \mathrm{~Hz}, 1 \mathrm{H}, \mathrm{CH}\left(\mathrm{CO}_{2} \mathrm{CH}_{3}\right)_{2}, 3.75(\mathrm{~s}, 3 \mathrm{H}\right.$, $\left.\mathrm{CH}\left(\mathrm{CO}_{2} \mathrm{CH}_{3}\right)_{2}\right), 3.77$ (s, $\left.3 \mathrm{H}, \mathrm{CH}\left(\mathrm{CO}_{2} \mathrm{CH}_{3}\right)_{2}\right), 3.83(\mathrm{~s}, 3 \mathrm{H}$, $\left.\mathrm{C}(\mathrm{CN}) \mathrm{CO}_{2} \mathrm{CH}_{3}\right) ;{ }^{13} \mathrm{C} \mathrm{NMR}\left(\mathrm{CDCl}_{3}, 125 \mathrm{MHz}\right) \delta 205.5$ $\left(\mathrm{CH}_{2} \mathrm{CH}_{2} \mathrm{COCH}_{3}\right), 168.5\left(\mathrm{CH}\left(\mathrm{CO}_{2} \mathrm{CH}_{3}\right)_{2}\right), 168.4$ $\left(\mathrm{CH}\left(\mathrm{CO}_{2} \mathrm{CH}_{3}\right)_{2}\right), 167.7\left(\mathrm{C}(\mathrm{CN}) \mathrm{CO}_{2} \mathrm{CH}_{3}\right), 117.2(\mathrm{CN})$, $53.9\left(\mathrm{CH}\left(\mathrm{CO}_{2} \mathrm{CH}_{3}\right)_{2}\right), 53.4\left(\mathrm{C}(\mathrm{CN}) \mathrm{CO}_{2} \mathrm{CH}_{3}\right), 53.1$ 
$\left(\mathrm{C}(\mathrm{CN}) \mathrm{CO}_{2} \mathrm{CH}_{3}\right), 52.73\left(\mathrm{CH}\left(\mathrm{CO}_{2} \mathrm{CH}_{3}\right)_{2}\right), 52.72$

$\left(\mathrm{CH}\left(\mathrm{CO}_{2} \mathrm{CH}_{3}\right)_{2}\right), 39.3\left(\mathrm{CH}_{2} \mathrm{CH}_{2} \mathrm{COCH}_{3}\right), 39.0\left(\mathrm{CHCH}_{3}\right), 30.2$ $\left(\mathrm{CH}_{2} \mathrm{CH}_{2} \mathrm{COCH}_{3}\right), 29.7\left(\mathrm{CH}_{2} \mathrm{CH}_{2} \mathrm{COCH}_{3}\right), 13.2\left(\mathrm{CHCH}_{3}\right)$.

Anal. Calcd for $\mathrm{C}_{15} \mathrm{H}_{21} \mathrm{NO}_{7}$ : C, 55.04; H, 6.47; N, 4.28. Found: C, 54.90; H, 6.61; N, 4.22.

The relative stereochemical configuration of $\mathbf{4}$ was

unequivocally determined by X-ray crystallographic analysis of crystals grown in diisopropyl ether as previously reported. ${ }^{7 b}$ Crystallographic data of $\mathbf{4}$ have been deposited at the
Cambridge Crystallographic Data Base (deposition No. CCDC 156544). Copies of the data can be obtained free of charge on application to the CCDC, 12 Union Road, Cambridge CB2 1EZ, UK (fax:+44 1223336 033;

E-mail: deposit@ccdc.cam.ac.uk).

Article Identifier:

1437-2096,E;2001,0,SI,0991,0994,ftx,en;Y03701ST.pdf 